\title{
Utilization of processed kola nut husk meal in poultry production: Effects on the performance, carcass, biochemical indicators, and antioxidant enzymes of broiler chickens
}

Olugbenga David Oloruntola ( $\nabla$ oloruntoladavid@gmail.com )

Adekunle Ajasin University https://orcid.org/0000-0002-2175-1490

\section{Research Article}

Keywords: Agricultural waste. Biochemistry indices. Growth. Oxidative stress. Poultry

Posted Date: November 15th, 2021

DOI: https://doi.org/10.21203/rs.3.rs-1024596/v1

License: (c) (i) This work is licensed under a Creative Commons Attribution 4.0 International License. Read Full License

Version of Record: A version of this preprint was published at Waste and Biomass Valorization on February 22nd, 2022. See the published version at https://doi.org/10.1007/s12649-022-01730-z. 


\section{Abstract}

This study looked at the effects of processed kola nut husks meal (PKHM) utilization as a feed ingredient on broiler chicken in a 42-day feeding trial. Kola nut pod husks were processed into a PKHM using ash treatment and rumen liquor fermentation. Three experimental diets were developed at both the starter and finisher phases, with PKHM included at 0,4 , and $8 \%$, and dubbed diets 1,2 , and 3 , respectively. In a fully randomised design, 240 Arbor Acres broiler chicks were randomly assigned to three treatments (10 birds per replicate). Except for the significantly improved $(P<0.05)$ feed conversion ratio of broiler chickens fed diets 2 and 3 at the grower phase (22-42 days) and overall (0-42 days), the performance indices were not significantly $(P>0.05)$ affected by PKHM dietary inclusion. Broiler chicken carcass characteristics and relative internal organ weights remained constant $(P>0.05)$ through diets. The serum glutathione concentration in broiler chickens fed an 8 percent PKHM inclusive diet increased significantly $(P<0.05)$ than those on the control diet and 4 percent PKHM inclusive diet. When broiler chickens fed an 8 percent PKHM inclusive diet were compared to those fed a control diet, the serum catalase concentration was significantly higher $(P<0.05)$. The total serum protein, creatinine, alanine aminotransferase, aspartate transferase, and cholesterol levels remained constant $(P>0.05)$ regardless of dietary treatment. Dietary PKHM inclusion of up to $8 \%$ enhanced improved feed efficiency and increased antioxidant enzyme concentration and did not affect the serum biochemical indices concentration.

\section{Statement of Novelty}

Kola nut husk is one of the agro-wastes that contributes to environmental deterioration due to its underutilization. The kola nut husk is underutilised in broiler production due to its chemical constitution, minimal nutritional value, and poor digestion. In this research, kola nut husk meal was ash treated and rumen liquor fermented before being integrated at varying levels in the experimental diets and the performance characteristics, antioxidant status, serum protein, enzymes and biochemical were evaluated. The findings of this study could aid in the development of an agro-waste-based, low-cost functional feed for broiler chicks that incorporates the underutilised kola nut husk and other abundant agrowastes as macro-ingredients.

\section{Introduction}

Environmental contamination from excessive agro-waste disposal and low animal protein consumption due to high animal protein costs are two of the most challenging problems in developing countries [1, 2]. Agricultural operations produce agro-waste, making the environment squalid and polluting the atmosphere if it is not correctly disposed of or used productively [3]. Mainly, kola nut husk, cattle and poultry wastes, among others, are essential components of agro wastes. If not adequately disposed of or utilised for productive purposes, it could constitute a nuisance to the environment $[2,3,4]$.

A vast number of these agro wastes such as cassava peel [5], cocoa pod husk [4], cocoa bean shell meal $[6,7]$, cassava starch residue [8], rumen content and poultry wastes [2] were reported to be helpful as 
replacements for conventional feed ingredients in monogastric animal production.

Kolanut (Cola acuminata), a small tropical evergreen African tree, has a global output of 300,000 tons. The kola nut husk, which was previously considered waste, contains 130 grams of crude protein per kilogram, 71.3 grams of crude fibre per kilogram, and 2,546.9 calories per kilogram of gross energy [10, 1]. Kolanut husk, derived from processed kola nut fruits, is another useful agricultural waste product used to substitute maize in poultry feed production $[10,11]$. Kola nut husk was reported to contain some bioflavonoids, which can help in enhancing growth [11]. As a result, kola nut husk may be a good substitute for maize in broiler chicken diets, lowering environmental fouling and reducing livestock feeding costs $[5,10,12]$.

However, the anti-nutritional factors could deter nutritional availability in agro-waste such as kola nut husk, particularly when not adequately subjected to proper processing methods $[10,13]$. In a previous study, increased levels $(0,5,10,15$, and $20 \%)$ of kola nut husk in broiler chicken diets inhibited growth [12]. Nevertheless, the nutrient and the phytochemical composition of kola nut husk can be improved when subjected to one or a combination of processing methods [4, 14], such as fermentation [2], alkaline and urea treatment [15]. As earlier reported by Adeyeye et al. [4], the combination of ash treatment and rumen liquor fermentation improves the nutritional profile of cocoa pod husk, making it suitable for broiler chickens diet up to $8 \%$ inclusion level. It is rare to see kola nut husk treated with ash and rumen liquor fermentation, then used in broiler chicken output. As a result, this study aims to see how broiler chicken performance, carcass traits, serum antioxidant enzymes and serum biochemistry indices are affected by dietary inclusion of kola nut husk meal that has been ash treated and rumen liquor fermented.

\section{Materials And Methods}

\section{Study site and ethical approval}

The Department of Animal Health and Production Technology, The Federal College of Agriculture, Akure (FCAA), Research and Moral code Committee, ratified all experimental animal protocols for this research. The study was executed at The FCAA Research Farm [16].

\section{Kola Nut Husk Meal Processing}

As earlier described by Adeyeye et al. [16], kola nut husk was collected and altered into kola nut husk meal (KHM). The dried corn stalks were burnt to corn stalk ash. The corn stalk ash extract was then prepared according to Adeyeye et al. [16]. Using a cheesecloth, bovine rumen liquor was extracted from the rumen matter of recently butchered cattle and used right away. Sun-dried layer bird droppings were collected, ground, and stored in bags until they were required. Molasses was bought in Akure, Nigeria, from a well-known commercial animal feed mill. 
Kola nut husk meal was processed using the duet processing techniques of ash treatment and solid-state fermentation with the rumen liquor in this research $[14,16]$. In a black plastic vessel, the kola nut husk meal was meticulously mixed with corn stalk ash extract at 188 grams per litre and held in an anaerobic condition for a week. The kola nut husk meal that had been immersed in corn stalk ash extract was then drained, sunbaked for fourteen days, and tabbed the ash treated kola nut husk meal.

The ash treated kola nut husk meal was further subjected to rumen liquor fermentation [17] and was consecutively mixed with the $100 \mathrm{~g} / \mathrm{kg}$ layer droppings and $50 \mathrm{ml} / \mathrm{kg}$ molasses. After that, the blend of ash treated kola nut husk meal, layer droppings and molasses were showered with the newly collected bovine rumen liquor in a black plastic vessel and let to ferment anaerobically for a week. Subsequently, the fermented kola nut husk meal was sunbaked for seven days, explored for tannin [18], caffeine [19], theobromine [20], proximate composition [21], and after that tabbed processed kola nut husk meal (PKHM).

\section{Treatments and experimental design}

For the starter (1-21 days) and finisher (22-42 days) production phases of the experimental birds, three experimental diets were developed (Table 1), with PKHM included at $0 \%$ (diet 1), 4\% (diet 2), and 8\% (diet 3). Two hundred and forty 1-day old Arbor Acres broiler chicks were haphazardly apportioned to three diets (10 birds/replicate; 8 replicate/treatment) in a completely randomised design (CRD). The birds in each replicate were confined in a $200 \times 100 \mathrm{~cm}$ pen for the first week at a temperature of $31^{\circ} \mathrm{C} \pm 2$, which was gradually reduced by $2^{\circ} \mathrm{C}$ each week until the temperature reached $26^{\circ} \mathrm{C} \pm 2$. Luminance was given for a total of 23 hours per day. Throughout the experiment, the birds were given unlimited amounts of water and mash. 
Table 1

Composition of experimental diets

\begin{tabular}{|c|c|c|c|c|c|c|}
\hline \multirow[t]{4}{*}{ Ingredients (\%) } & \multicolumn{3}{|c|}{ Starter phase } & \multicolumn{3}{|c|}{ Finisher phase } \\
\hline & Diet 1 & Diet 2 & Diet 3 & Diet 1 & Diet 2 & Diet 3 \\
\hline & $0 \%$ & 4\% PKHM & $8 \%$ & 0\% PKHM & 4\% PKHM & $8 \%$ \\
\hline & PKHM & & PKHM & & & PKHM \\
\hline Soybean meal & 40.14 & 39.5 & 37.5 & 57.5 & 55.1 & 51.6 \\
\hline Maize & 52.06 & 48.7 & 46.7 & 28 & 27.8 & 27.5 \\
\hline Rice bran & - & - & - & 5 & 3 & 2.4 \\
\hline Vegetable oil & - & - & - & 0.2 & 0.8 & 1.2 \\
\hline Fish meal & 3 & 3 & 3 & 4 & 4 & 4 \\
\hline Bone meal & 3 & 3 & 3 & 3.5 & 3.5 & 3.5 \\
\hline Oyster shell & 0.9 & 0.9 & 0.9 & 0.9 & 0.9 & 0.9 \\
\hline *Premix & 0.3 & 0.3 & 0.3 & 0.3 & 0.3 & 0.3 \\
\hline Salt & 0.25 & 0.25 & 0.25 & 0.25 & 0.25 & 0.25 \\
\hline Lysine & 0.15 & 0.15 & 0.15 & 0.15 & 0.15 & 0.15 \\
\hline Methionine & 0.2 & 0.2 & 0.2 & 0.2 & 0.2 & 0.2 \\
\hline PKHM & 0 & 4 & 8 & 0 & 4 & 8 \\
\hline \multicolumn{7}{|l|}{ Analyzed indices } \\
\hline Crude protein (\%) & 23.60 & 23.49 & 23.00 & 20.51 & 20.19 & 20.15 \\
\hline Crude fiber (\%) & 3.68 & 4.09 & 4.43 & 3.83 & 3.96 & 4.28 \\
\hline \multicolumn{7}{|l|}{ Calculated indices } \\
\hline ME (kcal/kg) & 2957.32 & 2923.51 & 2900.02 & 3005.1 & 3011.7 & 3000.5 \\
\hline Methionine (\%) & 0.55 & 0.54 & 0.52 & 0.49 & 0.48 & 0.48 \\
\hline Lysine (\%) & 1.45 & 1.42 & 1.36 & 1.14 & 1.13 & 1.11 \\
\hline Ca (\%) & 1.06 & 1.05 & 1.09 & 0.91 & 0.93 & 0.94 \\
\hline
\end{tabular}

* $1 \mathrm{~kg}$ of vitamin-mineral premix contains: Vitamin D3 - 2,000,000IU; Vitamin K - 2,250mg; Vitamin A 10,000,000IU; Vitamin E - 20,000IU; Thiamine B1 - 1,750mg; Niacin - 27,500mg; Pantothenic acid 7,500mg; Biotin - 50mg; Choline chloride - 400g; Riboflavin B2 - 5,000mg; Pyridoxine B6 - 2,750mg; Antioxidant - 125g; Magnesium - 80 g; lodine - 1.2 g; Selenium - 200 mg; Cobalt - 200 mg; Zinc - 50 mg; Iron - 20 g; Copper - 5g; ME: Metabolisable energy; PKHM: Processed kola nut husk meal. 


\begin{tabular}{|c|c|c|c|c|c|c|}
\hline \multirow[t]{4}{*}{ Ingredients (\%) } & \multicolumn{3}{|c|}{ Starter phase } & \multicolumn{3}{|c|}{ Finisher phase } \\
\hline & Diet 1 & Diet 2 & Diet 3 & Diet 1 & Diet 2 & Diet 3 \\
\hline & $0 \%$ & 4\% PKHM & $8 \%$ & 0\% PKHM & 4\% PKHM & $8 \%$ \\
\hline & \multicolumn{2}{|l|}{ PKHM } & \multicolumn{2}{|l|}{ PKHM } & & PKHM \\
\hline Available P (\%) & 0.45 & 0.47 & 0.49 & 0.41 & 0.43 & 0.45 \\
\hline \multicolumn{7}{|c|}{$\begin{array}{l}\text { *1 kg of vitamin-mineral premix contains: Vitamin D3 - 2,000,000IU; Vitamin K - 2,250mg; Vitamin A } \\
\text { 10,000,000IU; Vitamin E - 20,000IU; Thiamine B1 - 1,750mg; Niacin - 27,500mg; Pantothenic acid - } \\
\text { 7,500mg; Biotin - 50mg; Choline chloride - 400g; Riboflavin B2 - 5,000mg; Pyridoxine B6 - 2,750mg; } \\
\text { Antioxidant - 125g; Magnesium - } 80 \text { g; lodine - 1.2 g; Selenium - } 200 \text { mg; Cobalt - } 200 \text { mg; Zinc - } 50 \text { mg } \\
\text { Iron - } 20 \text { g; Copper - 5g; ME: Metabolisable energy; PKHM: Processed kola nut husk meal. }\end{array}$} \\
\hline
\end{tabular}

\section{Performance of chickens, slaughtering, sample selection, and analysis}

The birds' body weight (BW) and their feed intake ( $\mathrm{Fl})$ were taken at a seven-day interval. After that, the birds' body weights gain (BWG) were calculated as the differences between the final weight and the initial weight. The feed conversion ratio (FCR) was calculated as the ratio of feed consumed to the weight gain.

At the end of the sixth week of the experiment, three birds per replication were hand-picked, labelled, weighed, and slaughtered by lacerating the experimental birds' jugular veins after stunning. The blood was allowed to flow into a plain sample collection bottle before centrifuging; the serum was then isolated and stored at $-20^{\circ} \mathrm{C}$ for analysis. The catalase (CAT) activity was determined using the method early described by Sinha, [22] while the serum glutathione peroxidase (GPx) was determined using the method described by Rotruck et al., [23]. A Reflectron ® Plus 8C79 (Roche Diagnostic, GombH Mannheim, Germany) was used to measure total protein, alanine aminotransferase (ALT), cholesterol, and aspartate aminotransferase (AST). After de-feathering, evisceration, and dressing, the birds' slaughtered weights and dressed percentages were determined. The liver, kidney, heart, lung, spleen, pancreas, kidney, gall bladder and gizzard of the birds were excised, weighed and expressed as a percentage of the slaughtered weight.

\section{Analysis of data}

The model: $\mathrm{V}_{\mathrm{ab}}=\mathrm{m}+\mathrm{e}_{\mathrm{d}}+\beta_{\mathrm{rh}}$ was adopted in this study. The $\mathrm{V}_{\mathrm{ab}}=$ any of the reaction variables; $\mathrm{m}=$ the complete mean; $e_{r}=$ effect of the $d$ th treatment ( $d=$ diets 1,2 , and 3 ) and $\beta_{\mathrm{gh}}=$ random error due to experimentation. SPSS version 20 was used to perform a one-way analysis of variance on the results. Duncan multiple range test of the same package was used to assess the variations between means [24].

\section{Results And Discussion}

\section{Composition of processed kola nut husk meal}


The phytochemical compositions of processed kola nut pod husk meal (PKHM) are shown in Figure 1. Compared to other indices such as crude protein, crude fibre, crude ash, and ether extract, the composition analysis demonstrates that PKMH has relatively high crude protein and nitrogen-free extract. PKHM also contains caffeine, theobromine, saponin, and tannin.

\section{Performance and carcass traits of broiler chickens fed PKHM inclusive diets}

The effects of PKHM on broiler chicken performance are shown in Table 2. Except for the significantly improved $(P<0.05)$ feed conversion ratio recorded in broiler chickens fed diets 2 and 3 at the grower phase and overall, the performance indices were not significantly $(P>0.05)$ affected by PKHM dietary inclusion.

Table 2

Effects of processed kola nut husk meal on the performance of broiler chickens

\begin{tabular}{|c|c|c|c|c|c|}
\hline & D1 & D2 & D3 & SEM & $P$ value \\
\hline & 0\%PKHM & 4\%PKHM & 8\% PKHM & & \\
\hline Starter phase & & & & & \\
\hline IBW (g/bird) & 40.61 & 40.93 & 40.84 & 0.08 & 0.35 \\
\hline BWG (g/bird) & 905.19 & 950.27 & 939.73 & 18.98 & 0.66 \\
\hline FI (g/bird) & 1577.77 & 1637.89 & 1794.82 & 35.56 & 0.05 \\
\hline FCR & 1.74 & 1.73 & 1.91 & 0.03 & 0.08 \\
\hline Grower phase & & & & & \\
\hline BWG (g/bird) & 1521.51 & 1671.79 & 1872.42 & 72.38 & 0.13 \\
\hline $\mathrm{FI}$ (g/bird) & 2779.53 & 2651.66 & 2931.16 & 80.68 & 0.42 \\
\hline FCR & $1.82^{\mathrm{a}}$ & $1.58^{\mathrm{b}}$ & $1.57^{b}$ & 0.04 & 0.02 \\
\hline Overall (0 to 4 & & & & & \\
\hline BWG (g/bird) & 2423.82 & 2622.06 & 2812.15 & 87.08 & 0.20 \\
\hline FI (g/bird) & 4357.30 & 4289.55 & 4725.98 & 105.26 & 0.20 \\
\hline FCR & $1.79^{a}$ & $1.64^{b}$ & $1.68^{\mathrm{b}}$ & 0.02 & 0.02 \\
\hline $\begin{array}{l}\text { Means within } \\
\text { nut husk mea } \\
\text { conversion ra }\end{array}$ & $\begin{array}{l}\text { letters are } \\
\text { al body we } \\
\text { rror mean. }\end{array}$ & $\begin{array}{l}\text { ificantly dif } \\
\text { BWG: Bod }\end{array}$ & $\begin{array}{l}\text { nt }(P<0.05 \\
\text { eight gain; }\end{array}$ & $\begin{array}{l}\text { HM: Proc } \\
\text { ed intak }\end{array}$ & $\begin{array}{l}\text { ed kola } \\
\text { R: Feed }\end{array}$ \\
\hline
\end{tabular}


The similar body weight gain in the experimental birds across the various dietary treatments in this study suggests that PKHM has akin nutritional attributes to the regular or standard ones and holds up the expected growth performance in broiler chicken.

It was previously stated that agrowastes could be a good feed ingredient in monogastric animal production if appropriately processed $[3,8,9]$. This study's growth performance results contradict earlier reports by Fabunmi et al. [10], who found that kola nut husk added to broiler diets at $10 \%, 30 \%$, and $50 \%$ with or without enzyme supplementation caused poor growth. However, the encouraging growth observed in the experimental birds fed PKHM in this study suggests that the processing methods used for the kola nut husk and the inclusion levels are relevant and practical. It has been suggested that agrowastes be processed to reduce or eliminate anti-nutrient interference with nutrient absorption at dangerously high concentrations $[2,9]$.

The feed conversion ratio, a pivotal factor for estimating feed efficiency in broiler production, is affected by feed quality [25]. Therefore, the improved feed conversion ratio recorded at the grower phase (22-42 days) and overall (0-42 days) in the broiler chickens fed PKMH inclusive diets further suggest that the test ingredient used did not compromise but instead improved the general quality of the experimental diet to favour the better conversion of feed to live weight. From another side, it was observed that the FCR of the birds at the starter phase was high. This observation cut across the entire treatment groups in this study implies that the cause is outside the dietary treatment being studied in the trial. Therefore, environmental conditions predisposing the birds to heat stress, particularly during the post brooding period, could have been responsible. Heat stress alters the regular feed intake, protein synthesis efficiency, carbohydrates metabolism and increases oxidative stress in broiler chickens [26].

Nutriment has a notable influence on the yield of high-quality meat from animals. Their relative organ weights are beneficial in predicting the harmful effects of test materials or diets $[27,28]$. Furthermore, toxins in the diet may be consumed and stored in different target tissues or organs, causing cell damage and altering healthy function and structure [4]. In this study, the broiler chicken carcass characteristics and relative internal organ weights remained constant $(P>0.05)$ through dietary treatments (Table 3$)$. This observation indicates that the phytochemicals in the test ingredient are at a safe level and have not caused any noticeable adverse effects. The PKHM has not harmed the development of the birds' consumable parts typical structure. The activity of phytochemicals in stabilizing or producing favourable effects on carcass was reported by Valenzuela-Grijalva et al. [29]. 
Table 3

Effects of processed kola nut husk meal on carcass traits and relative internal organs (\% Slaughter weight)

\begin{tabular}{|llllll|}
\hline & D1 & D2 & D3 & SEM & P value \\
& $\mathbf{0 \%}$ PKHM & 4\% PKHM & 8\% PKHM & & \\
\hline Slaughter weight (g/bird) & 2427.30 & 2608.25 & 2877.50 & 116.75 & 0.31 \\
\hline Dressed weight (g/bird) & 1872.30 & 1957.25 & 2186.25 & 86.69 & 0.34 \\
\hline Dressed percentage (\%) & 77.30 & 74.91 & 76.09 & 0.85 & 0.56 \\
\hline Heart & 0.35 & 0.40 & 0.40 & 0.02 & 0.64 \\
\hline Lung & 0.41 & 0.48 & 0.46 & 0.02 & 0.19 \\
\hline Spleen & 0.07 & 0.08 & 0.08 & 0.00 & 0.72 \\
\hline Liver & 1.62 & 1.49 & 1.50 & 0.11 & 0.87 \\
\hline Gizzard & 1.88 & 1.89 & 1.96 & 0.08 & 0.92 \\
\hline Pancrease & 0.15 & 0.18 & 0.19 & 0.01 & 0.51 \\
\hline Kidney & 0.54 & 0.55 & 0.47 & 0.03 & 0.63 \\
\hline Gall bladder & 0.13 & 0.11 & 0.11 & 0.01 & 0.60 \\
\hline PKHM: Processed kola nut husk meal; SEM: Standard error mean. & & \\
\hline
\end{tabular}

\section{The serum antioxidant enzymes of broiler chickens fed the PKHM inclusive diets}

The consequences of PKHM on serum antioxidant enzymes and serum biochemical constituents are revealed in Table 4. The serum glutathione concentration in broiler chickens fed an 8 percent PKHM inclusive diet increased significantly $(P<0.05)$ than those on the control diet and 4 percent PKHM inclusive diet. The increased serum antioxidant enzymes recorded in the experimental birds fed 8 percent PKHM inclusive diets in this study suggest the test ingredient has phytochemicals that have antioxidant activity [30,31]. By interacting with free radicals during the oxidative phase, these phytochemicals with antioxidant properties help reduce oxidation [32]. Antioxidant enzymes such as catalase and glutathione peroxidase in the blood protect cells from the damaging effects of reactive oxygen species [33]. In addition, antioxidants help protect macromolecules like proteins, nucleic acids, and lipids from oxidative damage by scavenging free radicals produced by biochemical reactions [31]. Catalase protects cells from peroxide toxicity and hydrogen lipid peroxidation. In addition, glutathione peroxidase protects cells from the harmful effects of oxidation by catalysing the degradation of numerous peroxidases and oxidising glutathione [3, 33]. In this study, when broiler chickens fed an 8 percent PKHM inclusive diet were compared to those fed a control diet, the serum catalase concentration was significantly higher $(P<0.05)$. This is of benefit and further unveils the antioxidant activity of PKHM. 
Table 4

Effects of processed kola nut husk meal (PKHM) on serum antioxidant enzymes and biochemical parameters broiler chickens

\begin{tabular}{|llllll|}
\hline & D1 & D2 & D3 & SEM & P value \\
& 0\% PKHM & 4\% PKHM & 8\% PKHM & & \\
\hline Serum antioxidant enzyme & & & & & \\
\hline Glutathione (Mmol/GSSG/min) & $10.59^{\mathrm{b}}$ & $10.89^{\mathrm{b}}$ & $14.59^{\mathrm{a}}$ & 0.74 & 0.02 \\
\hline Catalase (ku/ml) & $14.06^{\mathrm{b}}$ & $15.26^{\mathrm{ab}}$ & $16.50^{\mathrm{a}}$ & 0.06 & 0.04 \\
\hline Serum biochemical parameters & & & & & \\
\hline Total protein $(\mathrm{mg} / \mathrm{dl})$ & 6.20 & 5.85 & 5.90 & 0.23 & 0.83 \\
\hline Creatinine $(\mathrm{mg} / \mathrm{dl})$ & 0.67 & 1.97 & 1.49 & 0.34 & 0.33 \\
\hline Alanine amino transferase (U/l) & 13.50 & 7.65 & 17.80 & 2.49 & 0.28 \\
\hline Aspartate amino transferase (U/l) & 135.20 & 121.75 & 163.95 & 9.21 & 0.16 \\
\hline Cholesterol (mmol/l) & 3.16 & 3.05 & 2.79 & 0.12 & 0.52 \\
\hline
\end{tabular}

Means within a row with different letters are significantly different $(P<0.05)$; PKHM: Processed kola nut husk meal SEM: Standard error mean.

\section{The serum biochemical parameters of broiler chickens fed the PKHM inclusive diets}

Serum biochemistry is helpful for disease diagnosis for livestock animals because they reflect their health condition [34]. The serum's total protein, creatinine, alanine aminotransferase, aspartate transferase, and cholesterol levels remained constant $(P>0.05)$ regardless of dietary treatment.

The serum total protein concentration is commonly used to assess nutrition [35], while serum creatinine is a renal function indicator [36]. Alanine aminotransferase is a valuable enzyme for detecting liver damage [37], while cellular damage is indicated by an abnormally high level of aspartate transferase [38]. Arteriosclerosis is more likely in animals with elevated serum cholesterol levels [33]. Therefore, similar serum concentration levels of total serum protein, creatinine, alanine aminotransferase, aspartate transferase, and cholesterol recorded in the experimental birds across all the dietary treatments further support the wholesomeness of PKHM and its level of dietary inclusion adopted in this study.

\section{Conclusions}

In conclusion, dietary inclusion of PKHM up to $8 \%$ improved the feed efficiency, did not alter the serum biochemical indices and improved the broiler chickens' antioxidant status. Therefore, broiler chickens can tolerate up to $8 \%$ PKHM dietary inclusion level. 


\section{Declarations}

\section{Acknowledgements}

The author expresses his profound gratitude to the management of The Federal College of Agriculture, Akure, for allowing me to use the facilities in the Poultry Unit of the institution's Teaching and Research Farm and Laboratory. Dr Adeyeye S.A and Mr Ayodele S.O are also appreciated for their technical support in carrying out the feeding trial. Thanks to Mrs Oloruntola D.A for assisting in the birds' blood analysis.

\section{Author Contributions}

OOD conceived, designed, supervised the experiment, did the data collection and statistical analysis, and wrote the article.

\section{Funding}

This research was not supported by any institution or other organisation.

\section{Data Availability}

The datasets generated and analysed during this study are available from the corresponding author on reasonable request.

Conflict of interest The authors declare that they have no conflict of interest.

Ethical Approval and Consent to Participate This study was conducted according to the research ethics approved by the committee on research of the Department of Animal Science, Faculty of Agriculture, Adekunle Ajasin University, Akungba Akoko, Nigeria.

\section{References}

1. Georganas, A., Giamouri, E., Pappas, A.C., Papadomichelakis, G., Galliou, F., Manios, T., Tsiplakou, E., Fegeros, K., Zervas, G.: Bioactive compounds in food waste: A review on the transformation of food waste to animal feed. Foods. 9, 291 (2020)

2. Oloruntola, O.D., Agbede, J.O., Onibi, G.E., Igbasan, F.A., Ayodele, S.O.: Chemical characterisation, energy, and zinc bio-availability of cassava starch residues fermented with rumen liquor and different N-sources. Anim. Res. Int. 14(3), 2842-2859 (2017)

3. Sadh, P.K., Duhan, S., Duhan, J.S.: Agro-industrial wastes and their utilisation using solid-state fermentation: a review. Bioresour. Bioproces. 5, 1 (2018)

4. Adeyeye, S.A., Ayodele, S.O., Oloruntola, O.D., Agbede, J.O.: (2019) Processed cocoa pod husk dietary inclusion: effect on the performance, carcass, haematogram, biochemical indices, antioxidant enzyme, and histology of the liver and kidney in broiler. Bull. Nat. Res. Cent. 43, 54 (2019) 
5. Oloruntola, O.D., Agbede, J.O., Onibi, G.E., Igbasan, F.A.: (2016) Replacement value of rumen liquor fermented cassava peels for maize in growing rabbit diet. Archiv. Zootecn. 65(249),89-97 (2016)

6. Ogunsipe, M.H., Ibidapo, I., Oloruntola, O.D., Agbede, J.O.: Growth performance of pigs on dietary cocoa bean shell meal. Livest. Res. Rural Dev. 29(1) (2017)

7. Ogunsipe, M.H., Balogun, K.B., Oladepo, A.D., Ayoola, M.A., Arikewuyo, M.T.: Nutritive value of cocoa bean shell meal and its effect on growth and haematology of weaning rabbits. Nigerian J. Agric. Food. Env. 13(1), 23-28 (2017)

8. Oloruntola, O.D., Agbede, J.O., Onibi, G.E., Igbasan, F.A., Ayodele, S.O., Arogunjo, M.A., Ogunjo, S.T.: (2018a) Rabbits fed fermented cassava starch residue l: Effect on performance and health status. Arch. Zootecn. 67(260),578-586 (2018)

9. Oloruntola, O.D., Agbede, J.O., Onibi, G.E., Igbasan, F.A., Ogunsipe, M.H., Ayodele, S.O.: Rabbits fed fermented cassava starch residue II: Enzyme supplementation influence on performance and health status. Arch. Zootecn. 67(260), 588-595 (2018)

10. Fabunmi, T.B., Arotupin, D.J., Adegunloye, D.,V., Orumnuyi, M., Odole, B.S.: Effects of Kolanut Husk Formulated feed at graded levels on growth performance and health of Ross broilers with and without enzyme inclusion. Acta Scien. Agric. 3(2), 105-113 (2019)

11. Eburu, P.O., Ozung, P.O., Edem, R.O.: Replacing Dietary Maize with Kolanut Husk Meal can Influence Growth Performance and Apparent Nutrient Digestibility of Rabbits. Merit Res. J. Agric. Sci. Soil Sci. 8(1), 015-020 (2020)

12. Abioye, J.A., Fanimo, A.O., Bamgbose, A.M., Dipeolu, M.A., Olubamiwa, O.: Nutrient Utilisation, Growth and Carcass Performance of Broiler Chickens Fed Graded Levels of Kolanut Husk. The J. Poult. Sci. 43(4), 365-370 (2006)

13. Kolawole, S.E., Obueh, H.O.: A study of the oxalate, phytate and cyanide contents of selected Nigerian Foods and Diets in Akwa Ibom and Cross River States of Nigeria. African J. Food Sci. Techn. 4, 4447 (2013)

14. Adamafio, N.A., Cooper-Aggrey, E., Quaye, F.O., Laary, J.K., Ouaye, J.: Effectiveness of corn stalk ash in reducing tannin level and improving in vitro enzymatic degradation of polysaccharides in crop residues. Ghana J. Sci. 44, 87-92 (2004)

15. Adeyeye, S.A., Agbede, J.O., Aletor, V.A., Oloruntola, O.D.: Performance and carcass characteristics of growing rabbits fed diets containing graded levels of processed cocoa (Theobroma cacao) pod husk meal supplemented with multi-enzyme. J. Appl. Life Sci. Int. 17(2), 1-11 (2018)

16. Adeyeye, S.A., Agbede, J.O., Aletor, V.A., Oloruntola, O.D.: Processed cocoa (Theobroma cacao) pod husks in rabbits diet: Effect on haematological and serum biochemical indices. Asian J. Adv. Agric. Res. 2(4), 1-9 (2017)

17. Oloruntola, O.D., Agbede, J.O., Onibi, G.E., Igbasan, F.A.: Composition of cassava (Manihot spp.) peels fermented with bovine rumen liquor and different nitrogen sources. J Global Agric and Ecol 2(1), 26$35(2015)$ 
18. Shad, M.A., Nawaz, H., Rehma, T., Ikram, M.: Determination of biochemicals, phytochemicals and antioxidative properties of different part of Cichorium intybus L.: A comparative study. The J. Anim. Plant Sci. 23(4), 1060-1066 (2013)

19. Rade, I., Branislava, S., Matevz, P., Marija, B., Katarina, K., Borut, S.: Determination of Caffeine and associated compounds in food, beverages, natural products, pharmaceuticals, and cosmetics by Micellar Electrokinetic Capillary Chromatography. J. Chromatographic Sci. 46, 137-143 (2008)

20. Bisto, M.S., Veloso, M.C.C., Pinheir,o, H.L.C., De Oliveira, R.F.S., Reis, J.O.N., De Andrade, J.B.: Simultaneous determination of caffeine, theobromine and theophylline by high-performance liquid chromatography. J. Chromatographic Sci. 40, 45 (2002)

21. AOAC., Association of Official Analytical Chemists, Official Methods of Analysis (16th edition), Inc., Arlington, VA. USA(1995)

22. Sinha, A.K.: Colorimetric Assay of catalase. Analytical Biochem 47(2), 389-394 (1972)

23. Rotruck, J.T., Pope, A.L., Ganther, H.E., Hafeman, D.G., Hoekstra, W.G.: Selenium: Biochemical role as a component of glutathione peroxidase. Sci. 179, 588-590 (1973)

24. SPSS., Statistical Package for Social Scientists. Version 20 (2011)

25. Yi, Z., Li, X., Luo, W., Zu, Z., Ji, C., Zhang, Y., Nie, Q., Zhang, D., Zhang, X.: Feed conversion ratio, residual feed intake and cholecystokinin type-A receptor gene polymorphisms are associated with feed intake and average daily gain in a Chinese local chicken population. J. Anim. Sci. Biotechn. 9, 50 (2018)

26. Kpomasse, C.C., Oke, O.E., Houndonougbo, K.T.: Broiler production challenges in the tropics: A review. Vet. Med. Sci. 7(3), 831-842 (2021)

27. Ayodele, S.O., Oloruntola, O.D., Agbede, J.O.: Effect of diet containing Alchornea cordifolia leaf meal on performance and digestibility of Weaner rabbits. World Rabbit Sci. 24, 201-206 (2016)

28. Oloruntola, O.D., Ayodele, S.O., Oloruntola, D.A.: Effect of pawpaw (Carica papaya) leaf meal and dietary enzymes on broiler performance, digestibility, carcass and blood composition. Rev. Elev. Med. Vet. Pays. Trop. 71(3) (2018)

29. Valenzuela-Grijalva, H.V., Pinelli-Saavedra, A., Muhlia-Almazan, A., Dominguez-Diaz, D., GonzalezRios, H.: Dietary inclusion effects of phytochemicals as growth promoters in animal production. J. Anim. Sci. Techn. 59, 8 (2017)

30. Zhang, Y., Gan, R., Zhou, Y., Li, A., Zu, D., Li, H.: Antioxidant phytochemicals for the prevention and treatment of chronic diseases. Molecules 20(12), 21138-21156 (2015)

31. Khan, W., Subhan, S., Shams, D.F., Afridi, S.G., Ullah, R., Shahat, A.A., Alqahtani, A.S., Antioxidant potential, phytochemicals composition, and metal contents of Daura alba. Biomed. Res. Int. 2019,1-8 (2019)

32. Lee, M.T., Lin, W.C., Yu, B., Lee, T.T.: Antioxidant capacity of phytochemicals and their effects on oxidative status in animals. Asian-Australasian J. Ani. Sci. 30(3), 299-308 (2017) 
33. Oloruntola, O.D., Agbede, J.O., Ayodele, S.O., Oloruntola, D.A.: Neem, pawpaw, and bamboo leaf meal dietary supplementation in broiler chickens: Effect on performance and health status. J. Food Biochem. e12723. (2018)

34. Nie, D., Zhao, G.J., Lin, N., Tang, Y., Cai, H., Shen, F., Liu, G., Zhang, J., Chen, E.: M., Haematological and serum biochemical reference values in Chinese water deer (Hydropotes inermis): a preliminary study. BMC Vet. Res. 16, 395 (2020)

35. Goldstein-Fuchus, D.J., LaPierre, A.F., Nutrition and kidney disease. Editor(s): Scott J. Gilbert, Daniel E. Weiner. National Kidney Foundation Primer on Kidney Diseases. 6th Edition, W.B. Saunders, pp. 467475: (2014)

36. Pimenta, E., Jensen, M., Jung, D., Schaumann, F., Boxnick, S., Truebel, H.: Effect of Diet on Serum Creatinine in Healthy Subjects During a Phase I Study. J Clin Med Res 8(11), 836-839 (2016)

37. Gwaltney-Brant, S.M., Nutraceuticals in hepatic diseases. Editor(s): Ramesh C. Gupta, Rajiv Lall, Ajay Srivastava, Nutraceuticals (Second Edition), Academic Press, Pp. 117-129: (2021)

38. Aulbach, A.D., Amuzie, C.J.: Biomarkers in nonclinical drug development. In: A Comprehensive Guide to Toxicology in Nonclinical Drug Development (Second Edition), Eds. Ali Said Faqi. Academic Press (2017)

\section{Figures}

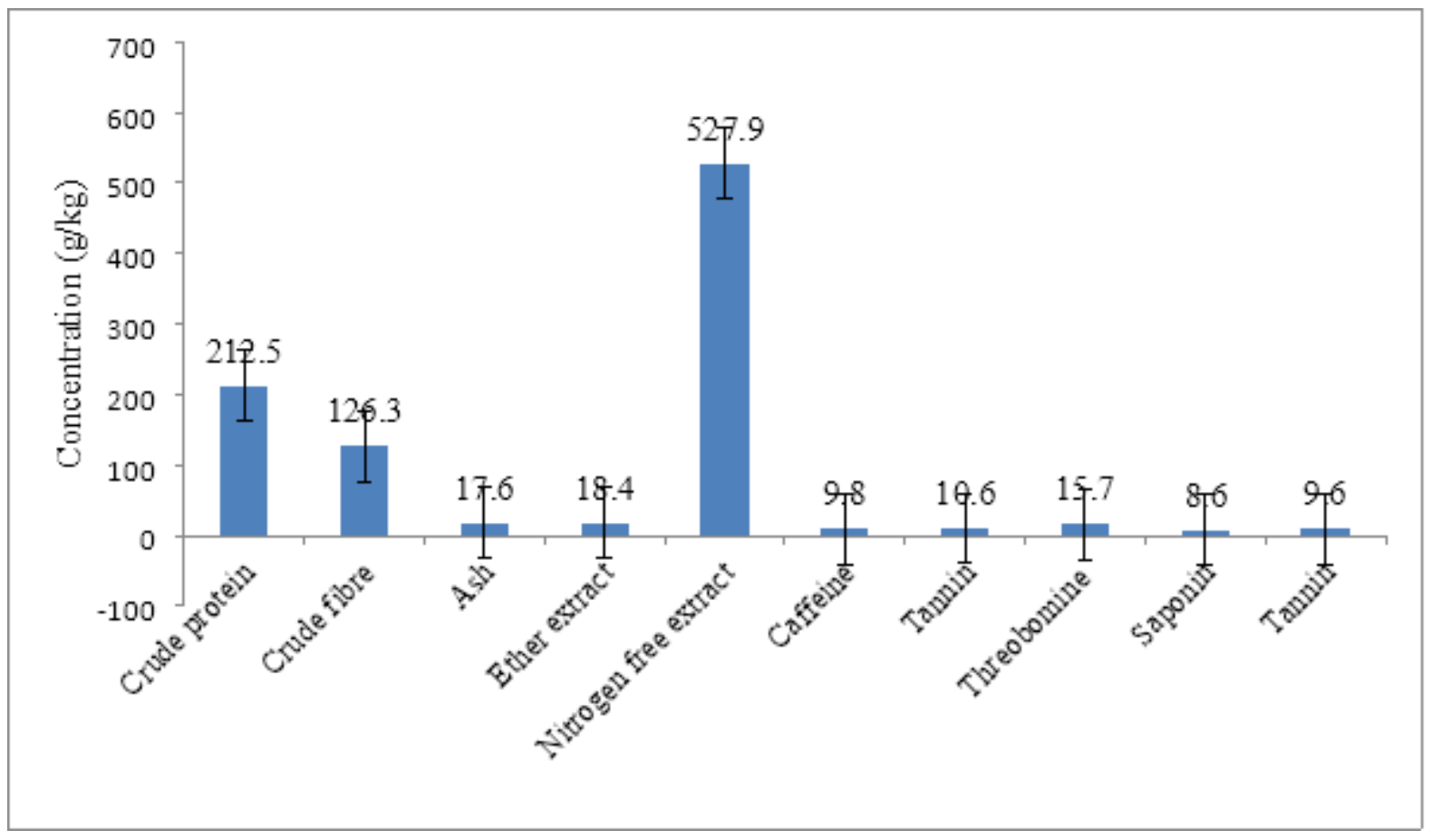

\section{Figure 1}

The phytochemical composition of processed kola nut husk meal 


\section{Supplementary Files}

This is a list of supplementary files associated with this preprint. Click to download.

- Graphicalabstract.png 